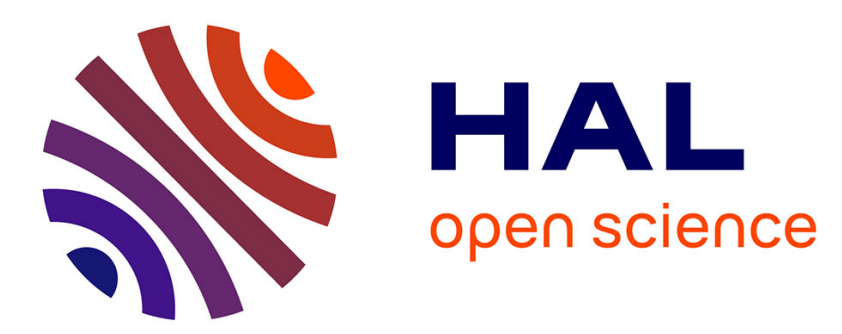

\title{
Quinone- and nitroreductase reactions of Thermotoga maritima 3 peroxiredoxin-nitroreductase hybrid enzyme
}

Zilvinas Anusevicius, Lina Misevičienè, Nicolas Rouhier, Jean-Pierre Jacquot

\section{To cite this version:}

Zilvinas Anusevicius, Lina Misevičienè, Nicolas Rouhier, Jean-Pierre Jacquot. Quinone- and nitroreductase reactions of Thermotoga maritima 3 peroxiredoxin-nitroreductase hybrid enzyme. Archives of Biochemistry and Biophysics, 2012, 528 (1), pp.50-56. 10.1016/j.abb.2012.08.014 . hal-01332162

\section{HAL Id: hal-01332162 \\ https://hal.univ-lorraine.fr/hal-01332162}

Submitted on 29 Nov 2017

HAL is a multi-disciplinary open access archive for the deposit and dissemination of scientific research documents, whether they are published or not. The documents may come from teaching and research institutions in France or abroad, or from public or private research centers.
L'archive ouverte pluridisciplinaire HAL, est destinée au dépôt et à la diffusion de documents scientifiques de niveau recherche, publiés ou non, émanant des établissements d'enseignement et de recherche français ou étrangers, des laboratoires publics ou privés. 
2 Quinone- and nitroreductase reactions of Thermotoga maritima 3 peroxiredoxin-nitroreductase hybrid enzyme

\author{
4 Q1 Žilvinas Anuševičius ${ }^{a}$, Lina Misevičienè ${ }^{a}$, Jonas Šarlauskas ${ }^{a}$, Nicolas Rouhier ${ }^{\text {b }}$, Jean-Pierre Jacquot ${ }^{\text {b }}$, \\ 5 Narimantas Čènas ${ }^{a, *}$ \\ 6 a Institute of Biochemistry of Vilnius University, Mokslininku 12, LT-08662 Vilnius, Lithuania \\ $7 \quad$ b Unité Mixte de Recherches 1136, Universite de Lorraine-INRA, IFR 110 Faculté des Sciences, BP 239, 54506 Vandoeuvre Cedex, France
}

\section{A R T I C L E I N F O}

\section{Article history:}

Received 6 August 2012

and in revised form 29 August 2012

Available online $\mathrm{xxxx}$

\section{Keywords:}

Flavoenzymes

Nitroreductase

Peroxiredoxin

Thermotoga maritima

Quinones

Nitroaromatic compounds

\begin{abstract}
A B S T R A C T
Thermotoga maritima peroxiredoxin-nitroreductase hybrid enzyme (Prx-NR) consists of a FMN-containing nitroreductase (NR) domain fused to a peroxiredoxin (Prx) domain. These domains seem to function independently as no electron transfer occurs between them. The reduction of quinones and nitroaromatics by NR proceeded in a two-electron manner, and follows a 'ping-pong' scheme with sometimes pronounced inhibition by quinone substrate. The comparison of steady- and presteady-state kinetic data shows that in most cases, the oxidative half-reaction may be rate-limiting in the catalytic cycle of NR. The enzyme was inhibited by dicumarol, a classical inhibitor of oxygen-insensitive nitroreductases. The reduction of quinones and nitroaromatic compounds by PrX-NR was characterized by the linear dependence of their reactivity $\left(\log k_{\text {cat }} / K_{\mathrm{m}}\right)$ on their single-electron reduction potentials $E_{7}^{1}$, while the reactivity of quinones markedly exceeded the one with nitroaromatics. It shows that NR lacks the specificity for the particular structure of these oxidants, except their single-electron accepting potency and the rate of electron self-exchange. It points to the possibility of a single-electron transfer step in a net two-electron reduction of quinones and nitroaromatics by T. maritima PrX-NR, and to a significant diversity of the structures of flavoenzymes which may perform the two-electron reduction of quinones and nitroaromatics.
\end{abstract}

(c) 2012 Published by Elsevier Inc.

\section{Introduction}

Bacterial oxygen-insensitive $\mathrm{NAD}(\mathrm{P}) \mathrm{H}$ :nitroreductases (NRs) contain flavin mononucleotide (FMN) ${ }^{1}$ in their active center, and perform a net two-electron reduction of nitroaromatic compounds to nitroso, and, subsequently, to hydroxylamine products ([1-11], and references therein). There are two groups of NRs with low sequence homology, which are similar with Escherichia coli NADPHdependent major nitroreductase-A [3], e.g., Vibrio harveyi FMNreductase [4], and Salmonella typhimurium nitroreductase [5], or with E. coli $\mathrm{NAD}(\mathrm{P}) \mathrm{H}-$ dependent minor nitroreductase-B [6], e.g.,

\footnotetext{
* Corresponding author.

E-mail address: narimantas.cenas@bchi.vu.lt (N. Čènas).

1 Abbreviations used: $\mathrm{Ar}-\mathrm{NO}_{2}$, nitroaromatic compound; $\mathrm{BCP}$, bacterioferritin comigratory protein; CB-1954, 5-(aziridin-1-yl)-2,4-dinitrobenzamide; DNBF, 4,6-dinitrobenzofuroxan; DZQ diaziridinyl-1,4-benzoquinone; $E E_{7}^{1}$, single-electron reduction potential at pH 7.0; FMN, flavin mononucleotide; Grx, glutaredoxin; $k_{\text {cat }}$, catalytic constant; $k_{\text {cat }} / K_{\mathrm{m}}$, second-order rate reaction rate constant; $K_{\mathrm{iq}}$, quinone substrate inhibition constant; MeDZQ, 2,5-dimethyl-3,6-diaziridinyl-1,4-benzoquinone; NQO1, $\mathrm{NAD}(\mathrm{P}) \mathrm{H}$ :quinone oxidoreductase; NR, nitroreductase; Prx, peroxiredoxin; Prx-NR, peroxiredoxin-nitroreductase hybrid enzyme; Q quinone; SN-23862, 5-(bis(2,2'chloroethyl-amino))-2,4-dinitrobenzamide; TNC, 1,3,6,8-tetranitrocarbazole; TNT 2,4,6-trinitrotoluene; VdWvol, van der Waals volume.
}

Enterobacter cloacae nitroreductase [2,7-9], Vibrio fisheri FMNreductase [10], and Thermus thermophilus NADH-oxidase [11]. The physiological role(s) of NRs are unclear except their possible antioxidant functions, because they are induced by oxidative stress and other environmental hazards [12]. On the other hand, bacterial NRs are of considerable interest due to their participation in the biodegradation of explosives and other polynitroaromatic environmental pollutants ([12,13], and references therein), and their possible utility in the antibody-, gene-, or virus- directed prodrug therapies ([14,15], and references therein).

It is generally accepted that a net two-electron (hydride) reduction of nitroaromatics by NRs is linked to the instability of their FMN semiquinone state, which makes the single-electron transfer thermodynamically unfavorable $[8,10]$. However, the other aspects of the catalytic mechanisms of bacterial oxygen-insensitive NRs, e.g., their substrate specificity, and the general mechanism of two-electron nitroreduction remain vaguely understood. Except for the more detailed examination of $E$. cloacae NR [7,16], most kinetic studies of other NRs were confined to a limited number of oxidants with sometimes poorly characterized reduction thermodynamics ([3,6,17], and references therein). The few available crystal structures of $E$. cloacae NR and E. coli NR-B with bound nitroaromatic compounds and other 
A<smiles>[R]C1=C(N2CC2)C(=O)C(N2CC2)=C([R])C1=O</smiles>

$\mathrm{R}_{1}=\mathrm{R}_{2}=\mathrm{H}$ (DZQ)

$\mathrm{R}_{1}=\mathrm{R}_{2}=\mathrm{CH}_{3}$ (MeDZQ)<smiles>CC(=O)C1(O)Cc2c(O)c3c(c(O)c2CC1OC1CC(N)C(O)C(C)O1)C(=O)c1ccccc1C3=O</smiles>

Daunorubicin
B<smiles>CN(c1c([N+](=O)[O-])cc([N+](=O)[O-])cc1[N+](=O)[O-])[N+](=O)[O-]</smiles><smiles>CN(c1c([N+](=O)[O-])cc([N+](=O)[O-])cc1[N+](=O)[O-])[N+](=O)[O-]</smiles>

Tetryl<smiles>CN(CCOO[Na])c1c([N+](=O)[O-])cc([N+](=O)[O-])cc1[N+](=O)[O-]</smiles>

Pentryl<smiles>O=[N+]([O-])c1cc([N+](=O)[O-])c2[nH]c3c([N+](=O)[O-])cc([N+](=O)[O-])cc3c2c1</smiles>

TNC<smiles></smiles>

DNBF<smiles>NC(=O)c1cc(N2CC2)c([N+](=O)[O-])cc1[N+](=O)[O-]</smiles>

CB-1954<smiles>NC(=O)c1cc(N(CCCl)CCCl)c([N+](=O)[O-])cc1[N+](=O)[O-]</smiles>

SN-23862

Fig. 1. The formulae of nontrivial quinones and nitroaromatic compounds used in this study.

aromatic ligands point to multiple and sometimes unproductive modes of binding [9,18-20]. A more thorough examination of the catalysis of NRs, including studies of their new representatives would be thus very informative in this respect.

Recently, an NR-related sequence has been found in the thermophilic bacterium Thermotoga maritima as a polypeptide of 321 amino acids (Genbank accession number NP_228196). It is constituted of a peroxiredoxin (Prx) domain of the BCP (bacterioferritin comigratory protein)-type at the $N$-terminus ( 140 amino acids) that contains a catalytic cysteine which is regenerated externally by the glutaredoxin (Grx) system, and an FMN-containing NR domain at the $C$-terminus ( $\sim 170$ amino acids), which contains an $\mathrm{NAD}(\mathrm{P}) \mathrm{H}$-binding site [21]. The extra 10 amino acids constitute a linker between the two domains. Previous physicochemical and structural characterization of its Prx domain [21] and of the holoenzyme [22] have shown that the Prx and NR domains function independently without the transfer of the redox equivalents between the domains, i.e., $\mathrm{NAD}(\mathrm{P}) \mathrm{H}$ does not provide the electrons for the reduction of Prx-linked oxidants, and the reduction of NRlinked oxidants does not involve the Prx domain [21].

In this study, we analyze the mechanisms of reactions of PrxNR with two classes of biologically important xenobiotics, quinones and aromatic nitrocompounds. Apart from the series of model compounds, the studies involved a number of therapeutically/toxicologically important substances such as antitumour agents DZQ, MeDZQ, daunorubicin, CB-1954, and SN-23862, and the environmental contaminants, such as the explosives TNT, tetryl, pentryl, TNC, and DNBF (Fig. 1).

\section{Materials and methods}

Enzymes and chemicals

The recombinant $T$. maritima PrX-NR was obtained as previously described [22]. Its concentration was determined according to the absorbance of FMN $\left(\varepsilon_{462}=11 \mathrm{mM}^{-1} \mathrm{~cm}^{-1}\right)$. E. cloacae NR was a generous gift of Dr. Ronald L. Koder (City College, CUNY, NY, USA). Model quinones and nitroaromatic compounds (the derivatives of 1,4-benzoquinone, 1,4-naphthoquinone, 9,10-phenanthrene quinone, 9,10-anthraquinone, and nitrobenzenes), NADH, NADPH, dicumarol, cytochrome $c$, superoxide dismutase (SOD), glucose-6phosphate, and glucose-6-phosphate dehydrogenase were obtained from Sigma-Aldrich, Applichem, and Fluka. Daunorubicin was obtained from Minmedprom (Russia). Diaziridinyl-1,4-benzoquinone (DZQ) and 2,5-dimethyl-3,6-diaziridinyl-1,4-benzoquinone (MeDZQ) were synthesized as described [23]. 5-(Aziridin-1-yl)2,4-dinitrobenzamide (CB-1954) and 5-(bis(2,2'-chloroethyl-amino))-2,4-dinitrobenzamide (SN-23862) synthesized according to the established methods [24], were the generous gift of Dr. Vanda Miškinienè (Institute of Biochemistry, Vilnius). 2,4,6-Trinitrotoluene (TNT), 2,4,6-trinitrophenyl- $N$-methylnitramine (tetryl), 2,4,6-trinitrophenyl- $N$-nitroaminoethylnitrate (pentryl), 1,3,6,8tetranitrocarbazole (TNC), and 4,6-dinitrobenzofuroxan (DNBF) were synthesized as described previously [7]. The purities of synthesized compounds were characterized by their melting points, TLC, ${ }^{1} \mathrm{H}$ NMR, UV, and IR spectroscopy and elemental analysis. The formulae of nontrivial quinoidal and nitroaromatic compounds are given in Fig. 1.

\section{Steady-state kinetic studies}

The steady-state kinetic measurements were performed spectrophotometrically using the Hitachi-557 spectrophotometer in $0.1 \mathrm{M}$ Tris- $\mathrm{HCl}$ ( $\mathrm{pH} 7.0$ ), containing $1 \mathrm{mM}$ EDTA, at $25^{\circ} \mathrm{C}$. The initial rates of enzymatic NADH-mediated quinone- or nitroreduction were determined by monitoring the oxidation of $\mathrm{NADH}$ $\left(\Delta \varepsilon_{340}=6.2 \mathrm{mM}^{-1} \mathrm{~cm}^{-1}\right)$, after the correction for the $\mathrm{NADH}$ oxidase activity of Prx-NR, $0.03 \mathrm{~s}^{-1}$, and for the nonenzymatic oxidation of NADH by high potential 1,4-benzoquinone and 2-methyl1,4-benzoquinone, or for the spectral changes at $340 \mathrm{~nm}$, corresponding to two(four)-electron reduction of nitrobenzenes [7]. The steady-state parameters of reactions, the catalytic constants $\left(k_{\text {cat }}\right)$ and the bimolecular rate constants $\left(k_{\text {cat }} / K_{\mathrm{m}}\right)$ of the oxidants at fixed concentration of NADH correspond to the reciprocal intercepts and slopes of Lineweaver-Burk plots, $[E] / v$ vs. $1 /[Q]$, where $v$ is the reaction rate, $[E]$ is the enzyme concentration, and $[Q]$ is the 

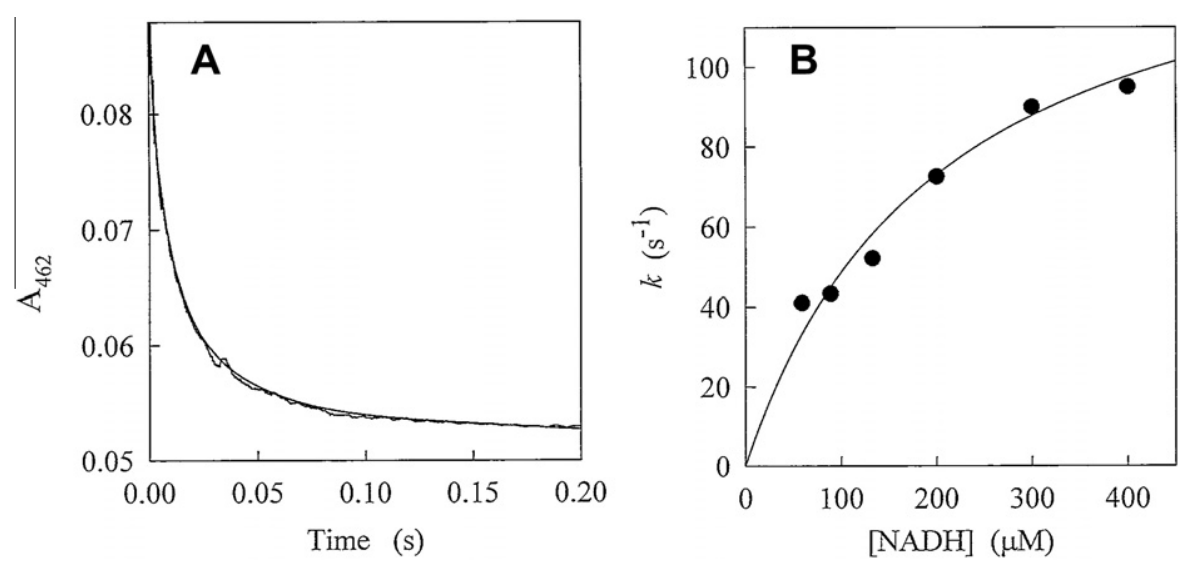

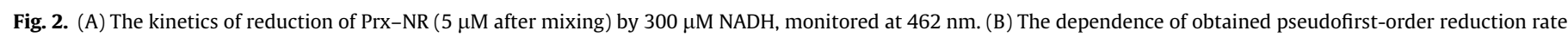
constant $(k)$ on NADH concentration.
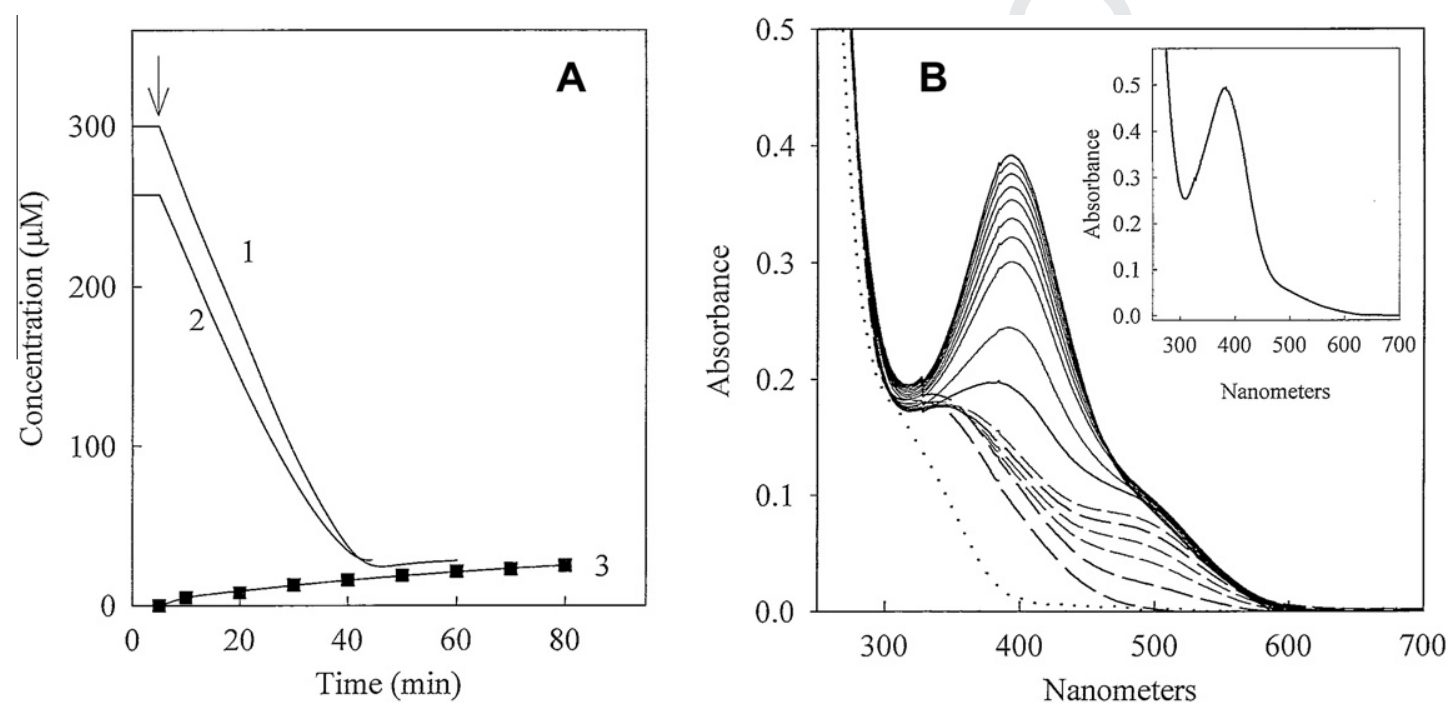

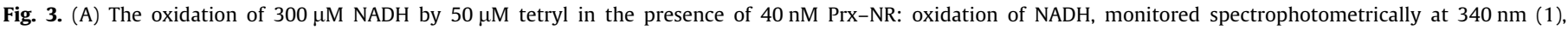

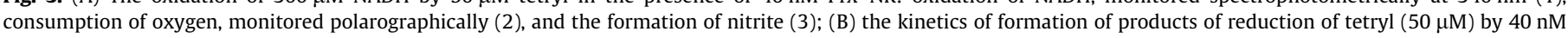

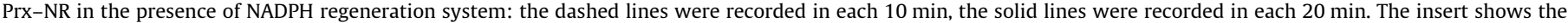
spectrum of the reduction product(s) of $50 \mu \mathrm{M}$ tetryl by $40 \mathrm{nM}$ E. cloacae nitroreductase after $2 \mathrm{~h}$ in the presence of NADPH regeneration system.

concentration of quinone or nitroaromatic oxidant. $k_{\text {cat }}$ represents a number of molecules of NADH oxidized by a single active center of the enzyme per second. These parameters were obtained by the fitting of kinetic data to the parabolic expression using Statistica (version 4.30, StatSoft, 1993), or SigmaPlot 2000 (version 6.10, SPSS Inc.). For the kinetics with a pronounced oxidizing quinone substrate $(Q)$ inhibition, the data were fit to Eq. (1), where $K_{\mathrm{iq}}$ is the apparent constant of quinone substrate inhibition at fixed concentration of NADH:

$\frac{v}{[E]}=\frac{k_{\text {cat }}}{1+K_{m} /[Q]+[Q] / K_{\text {iq }}}$

and further linearly extrapolated to $[\mathrm{NADH}]=0$. In separate experiments of nitroreduction, the NADPH regeneration system $(10 \mathrm{U} / \mathrm{ml}$ glucose-6-phosphate dehydrogenase, $10 \mathrm{mM}$ glucose-6-phosphate, and $15 \mu \mathrm{M} \mathrm{NADP}{ }^{+}$) has been used. In some experiments, the quinone/nitroaromatic-mediated reduction of cytochrome $c(50 \mu \mathrm{M})$ was monitored spectrophotometrically following an increase in absorbance at $550 \mathrm{~nm}\left(\Delta \varepsilon_{550}=20 \mathrm{mM}^{-1} \mathrm{~cm}^{-1}\right)$. The reaction rate was corrected for a direct reduction of $50 \mu \mathrm{M}$ cytochrome $c$ by Prx-NR, $0.2 \mathrm{~s}^{-1}$. The oxygen uptake was measured using the Clark- type electrode (Digital model 10, Rank Brothers Ltd.). The formation of nitrite was monitored spectrophotometrically, measuring an increase in the absorbance at $540 \mathrm{~nm}$ in the presence of sulfanilamide, naphthylethylene diamine dihydrochloride, and 4-fold diluted reaction mixture as described [7]. The solutions of $\mathrm{NaNO}_{2}(10-100 \mu \mathrm{M})$ were used for the calibration.

\section{Presteady-state kinetic measurements}

The presteady-state kinetic measurement of reduction of PrxNR by excess NADH was carried out by a stopped-flow SX.17 MV spectrophotometer (Applied Photophysics), using $0.1 \mathrm{M}$ Tris- $\mathrm{HCl}$ containing $1 \mathrm{mM}$ EDTA at pH 7.0 and $25^{\circ} \mathrm{C}$. The kinetics of absorbance decrease at $462 \mathrm{~nm}$ was analyzed according to the singleexponent fit using the Applied Photophysics software.

\section{Protein sequence alignment}

Protein sequence alignment of nitroreductase domain of PrxNR and group A and B nitroreductases and related enzymes was 

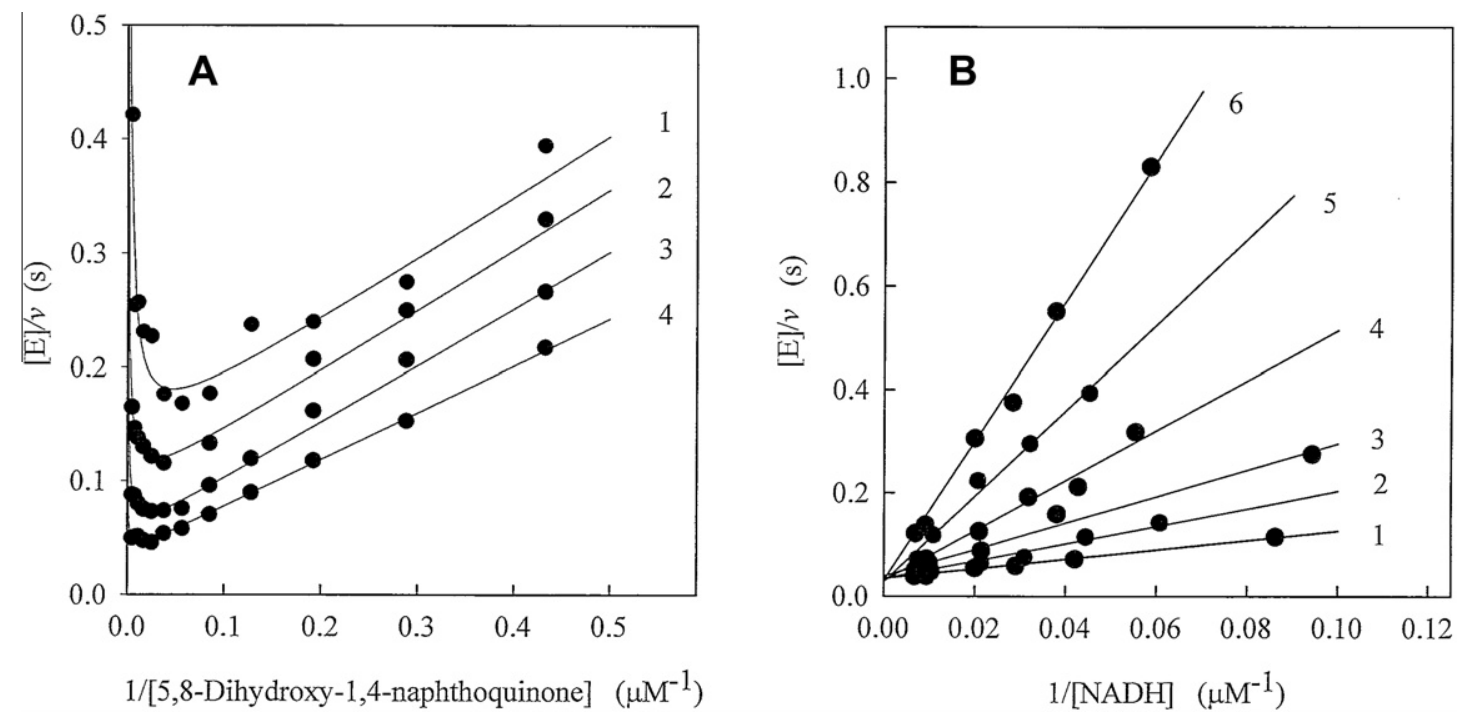

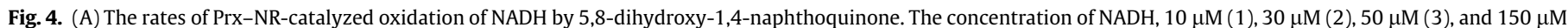

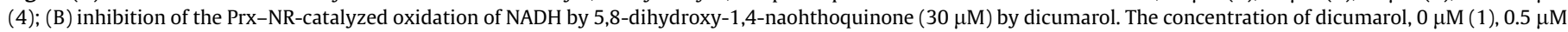
(2), $1.0 \mu \mathrm{M}$ (3), $2.5 \mu \mathrm{M}(4), 5.0 \mu \mathrm{M}(5)$, and $10 \mu \mathrm{M}(6)$.

performed using Clustal Omega software (www.ebi.ac.uk/Tools/ msa/clustalo/).

\section{Molecular volume calculations of oxidants}

Quantum mechanical calculations of the Van der Waals volumes (VdWvol) of compounds were performed using PC Spartan '04 package (Wavefunction, Inc. 1991-2003).

\section{Results}

Kinetic studies of the FMN reduction in Prx-NR

It has been shown previously that both NADH and NADPH reduce the FMN moiety of PrX-NR, leading to the disappearance of the absorbance of FMN in Prx-NR at $460 \mathrm{~nm}$ [22]. This is not observed with DTT, which can reduce the Prx redox moiety [22]. Because of the low NADH oxidase activity of Prx-NR, $0.03 \mathrm{~s}^{-1}$, which may just marginally affect the data of the measurements, the subsequent presteady-state reduction experiments were performed under the aerobic conditions. In the presence of an excess NADH, the FMN absorbance decrease at $460 \mathrm{~nm}$ followed the pseudofirst order kinetics (Fig. 2A). The dependence of the pseudofirst order rate constant $(k)$ on the concentration of NADH (Fig. 2B) yielded the maximal reduction rate constant, $146 \pm 24 \mathrm{~s}^{-1}$, and the apparent second-order reduction rate constant, $7.3 \pm 1.2 \times 10^{5} \mathrm{M}^{-1} \mathrm{~s}^{-1}$. Although NADPH displayed a similar capacity to reduce FMN, its activity towards Prx-NR was not investigated in the present paper, except its use in the NADPH regeneration system.

Two-electron reduction of quinones and nitroaromatic compounds by $\operatorname{Pr} x-N R$

Next, we attempted to find whether the reduction of quinones and nitroaromatics by PrX-NR occurs in a single- or two-electron manner. The percentage of the single-electron flux in the reduction of quinones by $\mathrm{NAD}(\mathrm{P}) \mathrm{H}$-oxidizing flavoenzymes may be determined using the 1,4-benzoquinone-mediated reduction of added cytochrome $c$, and is equal to the ratio between the cytochrome $c$ reduction rate and a doubled rate of $\mathrm{NAD}(\mathrm{P}) \mathrm{H}$ oxidation [25]. This is based on the fact that at $\mathrm{pH}<7.2$ the rate of reduction of cytochrome $c$ by 1,4-hydroquinone is negligible, whereas 1.4-benzosemiquinone, formed during single-electron reduction, reduces cytochrome $c$ at a high rate $\left(k \sim 10^{6} \mathrm{M}^{-1} \mathrm{~s}^{-1}\right)$ [25]. During PrxNR-catalyzed reduction of $50 \mu \mathrm{M} 1.4$-benzoquinone by $150 \mu \mathrm{M}$ $\mathrm{NADH}$, the rate of reduction of added cytochrome $c(50 \mu \mathrm{M})$ after the correction for the direct enzymatic reduction of cytochrome $c, 0.2 \mathrm{~s}^{-1}$, was equal to $12 \%$ of NADH oxidation rate. It shows that the percentage of single-electron flux makes up 6\%, which is consistent with the two-electron reduction mechanism. During the enzymatic oxidation of $150 \mu \mathrm{M}$ NADH by $50 \mu \mathrm{M}$ 2-methyl-1,4naphthoquinone (menadione) at $\mathrm{pH} 5.8$, menadione oxidized a close to stoichiometric amount of NADH in a single phase, which was followed by a slower subsequent oxidation of excess NADH. This is consistent with a two-electron reduction of menadione, because 2-methyl-1,4-naphthohydroquinone autooxidizes slowly at the acidic $\mathrm{pH}$, and is unable to support efficiently the enzymatic oxidation of excess $\mathrm{NAD}(\mathrm{P}) \mathrm{H}[26]$.

Using NADPH regeneration system, $p$-dinitrobenzene was reduced by PrX-NR in two(four)-electron manner into $p$-hydroxylaminonitrobenzene which possesses the characteristic absorbance at $340-350 \mathrm{~nm}$ (data not shown, the reference spectrum is given in Ref. [27]). During the enzymatic oxidation of NADH by $p$-dinitrobenzene, the reduction of added $50 \mu \mathrm{M}$ cytochrome $c$ at $15-20 \%$ of NADH oxidation rate takes place after the correction for the direct reduction of cytochrome $c$ by PrX-NR. This reaction was not inhibited by $100 \mathrm{U} / \mathrm{ml}$ superoxide dismutase. This is in line with the previously demonstrated direct reduction of cytochrome $c$ by hydroxylamine derivatives of polynitrobenzenes [7,28], and rules out the formation of nitroaromatic free radical intermediates which would be reoxidized by oxygen with the formation of superoxide. In addition, we found that using $500 \mu \mathrm{M}$ DTT which can reduce Prx moiety of PrX-NR [22], we failed to detect a measurable reduction of $p$-dinitrobenzene $(500 \mu \mathrm{M})$ by Prx-NR. Thus, these data additionally point to the absence of exchange in redox equivalents between NR and Prx moieties of Prx-NR, which could have contributed to the catalytically important reduction of NR-linked oxidants. The reduction of another nitroaromatic compound, tetryl (Fig. 1) by PrX-NR is accompanied by the oxidation of significant excess $\mathrm{NADH}$, uptake of $\mathrm{O}_{2}$ lower than stoichiometric to $\mathrm{NADH}$, and formation of nitrite (Fig. $3 \mathrm{~A}$ ). This reaction was accompanied 
Table 1

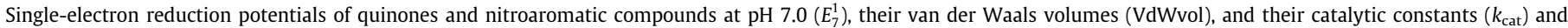
bimolecular rate constants $\left(k_{\text {cat }} / K_{\mathrm{m}}\right)$ in Thermotoga maritime Prx-NR-catalyzed reactions at pH 7.0 and $25{ }^{\circ} \mathrm{C}$ in the presence of $150 \mu \mathrm{M}$ NADH unless otherwise indicated.

\begin{tabular}{|c|c|c|c|c|c|}
\hline No. & Compound & $E_{7}^{1}(\mathrm{~V})^{\mathrm{a}}$ & $\operatorname{VdWvol}\left(\AA^{3}\right)$ & $k_{\text {cat }}\left(\mathrm{s}^{-1}\right)$ & $k_{\text {cat }} / K_{\mathrm{m}}\left(\mathrm{M}^{-1} \mathrm{~s}^{-1}\right)$ \\
\hline & Quinones & & & & \\
\hline 1 & 1,4-Benzoquinone & 0.09 & 124 & $70 \pm 10$ & $(1.0 \pm 0.4) \times 10^{7}$ \\
\hline 2 & 2-Methyl-1,4-benzoquinone & 0.01 & 142 & $27 \pm 4$ & $(1.7 \pm 0.1) \times 10^{6}$ \\
\hline 3 & 2,3-Dichloro-1,4-naphthoquinone & -0.035 & 187 & $34 \pm 1$ & $(6.9 \pm 0.8) \times 10^{6}$ \\
\hline 4 & 2,5-Diaziridinyl-1,4-benzoquinone (DZQ) & -0.054 & 199 & n.d. & $(1.7 \pm 0.1) \times 10^{6}$ \\
\hline 5 & 2,3-Dimethyl-1,4-benzoquinone & -0.07 & 160 & $30 \pm 3$ & $(1.1 \pm 2.9) \times 10^{7}$ \\
\hline 6 & 2,6-Dimethyl-1,4-benzoquinone & -0.08 & 160 & $56 \pm 4$ & $(5.6 \pm 1.4) \times 10^{6}$ \\
\hline 7 & 5-Hydroxy-1,4-naphthoquinone & -0.09 & 180 & $102 \pm 19^{b}$ & $(2.7 \pm 0.7) \times 10^{7}$ \\
\hline 8 & 5,8-Dihydroxy-1,4-naphthoquinone & -0.11 & 192 & $28 \pm 2^{\mathrm{b}}$ & $(2.5 \pm 0.2) \times 10^{6}$ \\
\hline 9 & 9,10-Phenathrenequinone & -0.12 & 218 & $111 \pm 14^{\mathrm{b}}$ & $(2.9 \pm 0.6) \times 10^{6}$ \\
\hline 10 & 1,4-Naphthoquinone & -0.15 & 168 & $99 \pm 9^{b}$ & $(1.8 \pm 0.2) \times 10^{6}$ \\
\hline 11 & 2-Methyl-5-hydroxy-1,4-naphthoquinone & -0.16 & 200 & $54 \pm 4$ & $(8.6 \pm 0.8) \times 10^{5}$ \\
\hline 12 & 2-Methyl-1,4-naphthoquinone & -0.20 & 187 & n.d. & $(1.2 \pm 0.2) \times 10^{5}$ \\
\hline 13 & 2,5-Dimethyl-3,6-diaziridinyl-1,4-benzoquinone (MeDZQ) & -0.23 & 238 & n.d. & $(4.7 \pm 0.4) \times 10^{3}$ \\
\hline 14 & Tetramethyl-1,4-benzoquinone & -0.26 & 197 & n.d. & $(4.6 \pm 0.5) \times 10^{3}$ \\
\hline 15 & 9,10-Anthraquinone-2,6-disulphonate & -0.25 & 266 & n.d. & $(3.4 \pm 0.3) \times 10^{3}$ \\
\hline 16 & 1,4-Dihydroxy-9,10-anthraquinone & -0.30 & 245 & n.d. & $(3.4 \pm 0.5) \times 10^{2}$ \\
\hline 17 & 1,8 -Dihydroxy-9,10-anthraquinone & -0.33 & 245 & n.d. & $(3.8 \pm 0.3) \times 10^{2}$ \\
\hline 18 & Daunorubicin & -0.34 & 600 & n.d. & $(6.8 \pm 0.5) \times 10^{3}$ \\
\hline 19 & 2-Hydroxy-1,4-naphthoquinone & -0.41 & 180 & n.d. & $(6.5 \pm 0.4) \times 10^{3}$ \\
\hline \multirow[t]{2}{*}{20} & 2-Hydroxy-3-methyl-1,4-naphthoquinone & -0.46 & 200 & n.d. & $(8.1 \pm 0.8) \times 10^{2}$ \\
\hline & Aromatic nitrocompounds & & & & \\
\hline 21 & $1,3,6,8$-Tetranitrocarbazole & -0.12 & 270 & $10 \pm 1.5$ & $(2.2 \pm 0.6) \times 10^{5}$ \\
\hline 22 & Pentryl & -0.14 & 266 & $15 \pm 2.0$ & $(5.8 \pm 1.4) \times 10^{5}$ \\
\hline 23 & Tetryl & -0.16 & 218 & n.d. & $(5.6 \pm 0.6) \times 10^{4}$ \\
\hline 24 & 2,4,6-Trinitrotoluene & -0.25 & 182 & n.d. & $(4.8 \pm 0.1) \times 10^{3}$ \\
\hline 25 & 1,4-Dinitrobenzene & -0.26 & 143 & n.d. & $(2.2 \pm 0.2) \times 10^{3}$ \\
\hline 26 & 4,6-Dinitrobenzofuroxane & -0.26 & 167 & n.d. & $(4.2 \pm 0.4) \times 10^{3}$ \\
\hline 27 & 1,2-Dinitrobenzene & -0.29 & 142 & n.d. & $260 \pm 40$ \\
\hline 28 & 4-Nitrobenzaldehyde & -0.32 & 142 & n.d. & $430 \pm 40$ \\
\hline 29 & 1,3-Dinitrobenzene & -0.35 & 143 & n.d. & $80 \pm 15$ \\
\hline 30 & CB-1954 & -0.38 & 217 & n.d. & $100 \pm 12$ \\
\hline 31 & SN-23862 & -0.43 & 266 & n.d. & $70 \pm 15$ \\
\hline 32 & 4-Nitrobenzyl alcohol & -0.48 & 147 & n.d. & $42 \pm 10$ \\
\hline 33 & Nitrobenzene & -0.49 & 123 & n.d. & $11 \pm 2.0$ \\
\hline
\end{tabular}

${ }^{\text {a }} E_{7}^{1}$ values taken from Refs. [31-34].

b $k_{\text {cat }}$ determined by extrapolation to infinite concentrations of NADH and quinone substrate according to a 'ping-pong' scheme.

by the reduction of added cytochrome $c$ at 18-25\% NADH oxidation rate, which also was not inhibited by $100 \mathrm{U} / \mathrm{ml}$ superoxide dismutase. The spectral changes of tetryl during the reduction by PrX-NR using the NADPH regeneration system are similar to those taking place during E. cloacae NR-catalyzed reaction [7], with a final formation of product(s) absorbing at $380-385 \mathrm{~nm}$ (Fig. 3B). Thus, our findings are in line with a net two(four)-electron of tetryl by Prx-NR, followed by the further reduction, and the subsequent $\mathrm{N}$-denitration of its (di)hydroxylamine derivatives [7]. In this case, the nonstoichiometric uptake of $\mathrm{O}_{2}$ accompanying the oxidation of excess NADH by tetryl may be attributed to the oxidation of its dihydroxylamine derivatives by $\mathrm{O}_{2}$, which is characteristic for dihydroxylamine derivatives of other polynitroaromatic compounds such as TNT $[29,30]$.

Steady-state kinetic studies and substrate specificity of quinone- and nitroreductase reactions of Prx-NR

At fixed concentrations of NADH and varied concentrations of 5,8-dihydroxy-1,4-naphthoquinone (naphthazarine), the steadystate kinetics of Prx-NR is characterized by a 'ping-pong' scheme with a pronounced quinone-substrate inhibition (Fig. 4A). The inhibition constant for naphthazarin, $K_{\mathrm{iq}}$, decreased with a decrease in NADH concentration, thus showing that naphthazarin is a competitive inhibitor with respect to NADH that binds to the oxidized enzyme form. The $K_{\mathrm{iq}}$ for naphthazarin obtained by extrapolation to [NADH] $=0$, was equal to $95 \pm 18 \mu \mathrm{M}$. The $k_{\text {cat }}$ of this reaction determined by the extrapolation of the maximal reaction rate to the infinite concentration of NADH in the plot $[E] / V_{\max }$ vs. 1/ [NADH], was equal to $28 \pm 2.0 \mathrm{~s}^{-1}$. The $k_{\mathrm{cat}} / K_{\mathrm{m}}$ for NADH obtained using 5,8-dihydroxy-, 5-hydroxy-1,4-naphthoquinone, or 9,10phenanthrenequinone as electron acceptors was equal to $7.2 \pm 1.5 \times 10^{5} \mathrm{M}^{-1} \mathrm{~s}^{-1}$, i.e., close to the apparent second-order reduction rate constant obtained in the presteady-state studies. We also found that Prx-NR was inhibited by dicumarol, a classical inhibitor of oxygen-insensitive NRs [6,7,10] (Fig. 4B), which acted as a competitive inhibition with respect to NADH with $K_{\mathrm{i}}=0.70 \pm 0.03 \mu \mathrm{M}$, thus showing that it competes for the NADH binding site in the oxidized enzyme form.

In order to characterize the oxidizing substrate specificity for Prx-NR, the main problem is to distinguish the roles of their electron(hydride)-accepting potency and structural peculiarities. For this reason, we studied the reduction of a series of quinones and nitroaromatic compounds with varying electron/hydride accepting potency (single-electron reduction potential, $E_{7}^{1}$ ), and steric parameters (Van der Waals volume, VdWvol) (Table 1). The use of $E_{7}^{1}$ in the analysis of two-electron(hydride) transfer is justified, because there exists a parallel between the thermodynamics of electron and hydride transfer in quinone reduction [10,31]. The thermodynamics of two-electron reduction of nitroaromatic compounds is less understood, because their electrochemical reduction in aqueous media is irreversible [35]. However, the reduction of nitroaromatic compounds $\left(\mathrm{Ar}-\mathrm{NO}_{2}\right.$ ) into their nitroso derivatives ( $\mathrm{Ar}-\mathrm{NO}$ ) proceeds with the rate-limiting hydride transfer:

$\mathrm{Ar}-\mathrm{NO}_{2}+2 \mathrm{e}^{-}+\mathrm{H}^{+} \rightarrow \mathrm{Ar}-\mathrm{N}(\mathrm{OH}) \mathrm{O}^{-}$, 


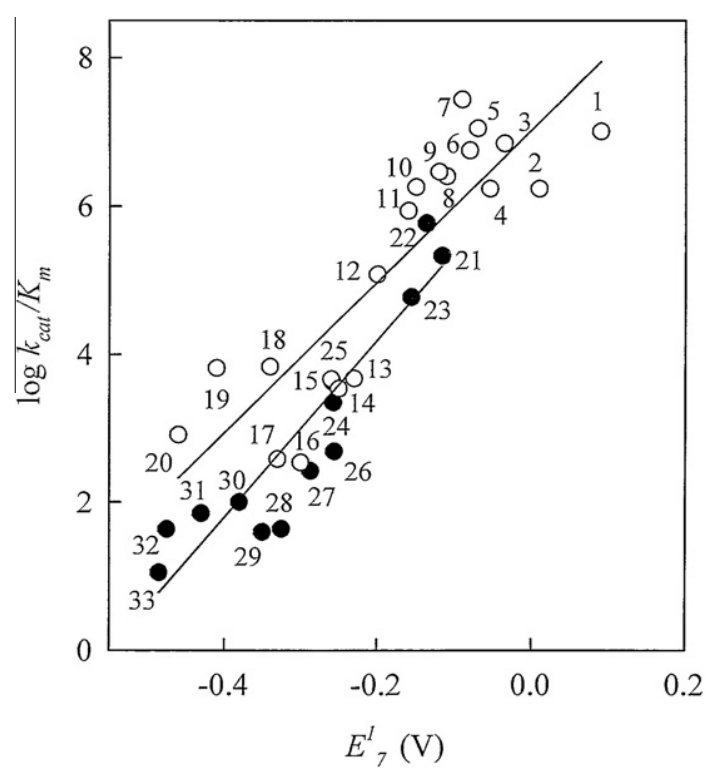

Fig. 5. The relationship between the $\log k_{\text {cat }} / K_{\mathrm{m}}$ of quinones (blank circles) and nitroaromatic compounds (solid circles) in Prx-NR-catalyzed reduction, and their single-electron reduction potentials at $\mathrm{pH} 7.0\left(E_{7}^{1}\right)$. The numbers of quinone and nitroaromatic compounds, their redox potentials, and their reduction rate constants are given in Table 1 .

with the subsequent fast protonation and dehydration of $\mathrm{Ar}$ $\mathrm{N}(\mathrm{OH}) \mathrm{O}^{-}[7,32]$. The heats of formation of $\mathrm{Ar}-\mathrm{N}(\mathrm{OH}) \mathrm{O}^{-}$obtained by the quantum mechanical calculations show a good correlation with the heats of formation of nitroaromatic anion-radicals (Ar$\mathrm{NO}_{2}{ }^{-}$), and also with the values of their $E_{7}^{1}$ [7]. For these reasons, $E_{7}^{1}$ was used in the description of the reactivity of nitroaromatics as well. As it is shown in Fig. 5 , the $\log k_{\text {cat }} / K_{\mathrm{m}}$ of reduction of quinones exhibited a linear but rather scattered positive dependence on their $E_{7}^{1}$ values $\left(r^{2}=0.873, \mathrm{~F}(1,18)=57.39\right)$. The similar trend was observed in the reduction of nitroaromatics $\left(r^{2}=0.872\right.$, $\mathrm{F}(1,11)=74.61)$. One may note that the reactivity of nitroamatic compounds is by one-two orders of magnitude lower than that of quinones possessing the same value of $E_{7}^{1}$ (Fig. 5). An introduction of VdWvol of quinones or nitroaromatics (Table 1 ) as the second variable in the multiparameter regression did not improve the correlations.

\section{Discussion}

In this work, we characterized quinone- and nitroreductase reactions of a hybrid peroxiredoxin-nitroreductase protein ( $P r x-$ NR) of anaerobic thermophilic bacterium T. maritima. Prx-NR is a relatively unique protein, being present only in some thermotogales. Not entirely in line with our initial expectations, the flavoprotein domain does not serve as a peroxiredoxin reductase in this case, since no electrons are exchanged between the NR and Prx domain $[22,36]$.

The kinetic characterization of Prx-NR (Figs. 2-5) is important in view of the vaguely understood mechanism(s) of the two-electron reduction of quinones and nitroaromatic compounds by different nitroreductases. As a thermophilic enzyme, PrX-NR is also interesting in the context of the biodegradation of nitroaromatic and other redox active environmental pollutants, because the use of thermophilic microorganisms in the bioremediation may contribute to the increased operational longevity of the systems [37,38].

To some extent, Prx-NR shares the properties of group B nitroreductases, because it uses both NADH and NADPH as the reducing substrates. However, the sequence analysis of its NR domain (res- idues 142-321, GenBank accession number NP_228196) revealed a modest homology, 20-24\%, with the sequences of $E$. coli NR-B (NC_000913.2), and E. cloacae NR (M6803). More important, the residues analogous to Phe-124, Phe-70, Ser-40, Lys-14. and Lys74 which participate in the binding of nitroaromatic compounds or the inhibitor dicumarol in E. coli NR-B or E. cloacae NR $[6,9,18,19]$, are absent in Prx-NR (data not shown). On the other hand, the comparison of PrX-NR sequence with that of $E$. coli NRA (Protein Data Bank Entry $1 \mathrm{BKJ}$ ) also shows a modest homology, $18 \%$, but also points to a possible conservation of several residues participating in the binding of the isoalloxazine ring of FMN, Arg15 (Arg-154 in Prx-NR), Gly-130,131 (Gly-235 and Arg-236 residues in PrX-NR), and also Tyr-128 (substituted into aromatic Phe-260 in Prx-NR) [39] (data not shown). Thus, it is possible that Prx-NR may share some properties of group A nitroreductases as well. In addition, the absence of conserved analogues for Phe-124 and Ser-40 which participate in the binding of dicumarol in E. coli NR-B and homologous NADPH:FMN oxidoreductase of $V$. fisheri $[10,18,19]$, may be responsible for the relatively weak binding of dicumarol by Prx-NR, $K_{\mathrm{i}}=0.7 \mu \mathrm{M}$ (Fig. 4B), which is less efficient than in the case of $E$. cloacae NR $\left(K_{\mathrm{i}}=0.06 \mu \mathrm{M}\right.$ [7]), or mammalian $\mathrm{NAD}(\mathrm{P}) \mathrm{H}$ : quinone oxidoreductase (NQO1, $K_{\mathrm{i}}=0.01-$ $\mu \mathrm{M}[40])$.

Considering the mechanism of catalysis of PrX-NR, it follows a 'ping-pong' scheme (Fig. 4A) like in other oxygen-insensitive NRs of $E$. coli and E. cloacae with quinone substrate inhibition, thus showing that $\mathrm{NAD}(\mathrm{P}) \mathrm{H}$ and electron acceptors bind at the same site in the oxidized and reduced enzyme forms, respectively $[3,6]$. The maximal rate of reduction of FMN of Prx-NR by $\mathrm{NADH}$, $146 \pm 24 \mathrm{~s}^{-1}$ (Fig. 2B) is lower than that of E. coli NR-B, $>500 \mathrm{~s}^{-1}$ [17], and E. cloacae NR, $>1000 \mathrm{~s}^{-1}$ [7]. The comparison of presteadyand steady-state kinetic data of Prx-NR (Fig. 2B,4A, Table 1) shows that the oxidative half-reaction is rate-limiting in the catalysis, with the exception of 5-hydroxy-1,4-naphthoquinone, 1,4-naphthoquinone, and 9,10-phenanthrene quinone, where the reductive half-reaction may be partly rate-limiting. Similarly, the oxidative half-reaction is a rate-limiting step in the reduction of CB-1954, menadione, and nitrofurazone by E. coli NR-B [17], and, probably, in the reduction of the low-potential oxidants by E. cloacae NR $[7,16]$. Thus, in this aspect, PrX-NR of T. maritima is similar to the above B group nitroreductases.

The most interesting problem in our case is the elucidation of the oxidizing substrate specificity for Prx-NR in the context of other oxygen-insensitive NRs. In the reactions of E. coli NR-A and NR-B, the reactivity of the oxidants increased upon increase in their reduction potential, in order 4-nitrobenzoic acid and CB-1954 $\left(E_{7}^{1} \approx\right.$ $-0.40 \mathrm{~V})<$ nitrofurazone and menadione $\left(E_{7}^{1}=-0.25 \mathrm{~V}-\right.$ $-0.20 \mathrm{~V}$ ) to $-0.20 \mathrm{~V})<1,4$-benzoquinone $\left(E_{7}^{1}=0.09 \mathrm{~V}\right)[3,6,17]$, although this dependence has not been thoroughly analyzed. On the other hand, E. cloacae NR was characterized by a parabolic dependence of $\log k_{\mathrm{cat}} / K_{\mathrm{m}}$ of nitroaromatic compounds on their $E_{7}^{1}$ [7]. The reactivity of quinones towards $E$. cloacae NR also displayed a parabolic dependence on their $E_{7}^{1}$, although their reactivity was generally by one order of magnitude lower than that of nitroaromatic compounds with the same reduction potential [16]. It shows that E. cloacae NR exhibited a certain preference towards nitroaromatic compounds in comparison to quinones. This enzyme was also characterized by a certain substrate specificity, because it discriminated the compounds with large WdWvol such as daunorubicin, and, possibly, 9,10-anthraquinones, and also displayed an enhanced reactivity towards 2-hydroxy-1,4-naphthoquinones [16]. However, the data of Fig. 5 show that none of these features are characteristic for Prx-NR, which shows little sensitivity to the structure of the oxidants. Besides, the enhanced reactivity of quinones in comparison to nitroaromatic compounds is similar to the regularities in the reactions of single-electron transferring flavoenzymes dehydrogenases- 
electrontransferases, such as NADPH: cytochrome P-450 reductase and ferredoxin:NADP ${ }^{+}$reductase [41,42]. In these cases, the enhanced reactivity of quinones is attributed to the high electron self-exchange rate constant of quinone/semiquinone redox couple, $\sim 10^{8} \mathrm{M}^{-1} \mathrm{~s}^{-1}$ [43], which significantly exceeds that of $\mathrm{ArNO}_{2}$ / $\mathrm{ArNO}_{2}{ }^{-}$redox couple, $\sim 10^{5} \mathrm{M}^{-1} \mathrm{~s}^{-1}$ [44]. Thus, it may point to a multistep $\left(\mathrm{e}^{-}, \mathrm{H}^{+} . \mathrm{e}^{-}\right)$mechanism in the two-electron reduction of quinones and nitroaromatic compounds by Prx-NR with a partly limiting step of first electron transfer. In addition, in terms of $k_{\text {cat }} /$ $K_{\mathrm{m}}$, the reactivity of quinone- and nitroaromatic oxidants towards Prx-NR is by one or two orders of magnitude lower than towards E. coli NR-B and E. cloacae NR (Table 1, Fig. 5, [7,16,17]). Here we may also consider some decline in the driving force for the reaction, because the standard potential for FMN of Prx-NR is equal to $-0.185 \mathrm{~V}$ at $\mathrm{pH} 8.0$ [22], which corresponds to $E_{7}^{1}=-0.125$ to $-0.155 \mathrm{~V}$ at $\mathrm{pH} 7.0$. This is more positive than the $E^{\mathrm{O}}{ }_{7}$ value for $E$. cloacae NR, $-0.190 \mathrm{~V}[8]$, and therefore it may decrease the reactivity of quinones and nitroaromatic compounds towards PrX-NR. On the other hand, taken together with the relatively inefficient inhibition of Prx-NR by dicumarol (Fig. 4B), our data may also point to a relatively inefficient and structure-unspecific binding of quinones and nitroaromatic compounds in the active center of NR domain of Prx-NR, i.e., to the flexibility of its active center. In this case, the thermodynamics of hydride(electron) transfer, and, possibly, the internal electron self-exchange in the separate series of the oxidants may play a major role in the determination of their reactivity. To some extent, this is characteristic for the active center of $E$. coli NR-B, where nitrofurazone was found to bind in the unproductive conformation [20], and the binding of CB-1954 occurred at two distant domains $[18,19]$. Taken together, our data testify in favor of the considerable but yet insufficiently studied diversity among the possible structural motifs of flavoenzymes prerequisite for the two(four)-electron reduction of nitroaromatic compounds. We also suggest that our data may provide some information linking the mechanisms of single- and two-electron reduction of quinones by flavoenzymes, thus complementing our previous studies $[31,45]$. The latter points to the stability of the flavin semiquinone state as to the most important factor deciding the single- or two-electron reduction of quinones, and also to a minor role of the surroundings of the isoalloxazine ring, which may be putatively responsible for the appropriate binding and activation of these oxidants [45]. One may note that no detectable formation of FMN semiquinone at 380 or $600 \mathrm{~nm}$ has been observed during the potentiometric titration of FMN of Prx-NR [22], which points to its instability like in $E$. cloacae NR and $V$. fisheri FMN reductase $[8,10]$. Thus, concerning the further studies of these physiologically important reactions, our next aims are to characterize the role of the interface between the NR and Prx domains in the binding of the oxidizing substrates and inhibitors for NR, and its impact on their reduction mechanism. The preliminary studies of the isolated NR domain of Prx-NR [22] show that it reduces quinones in two-electron manner, although with a decreased by $1.5-2.5$ times reactivity.

\section{Acknowledgments}

This work was in part supported by EGIDE and Lithuanian Scientific Council (programme Gilibert).

\section{References}

[1] F.J. Peterson, R.P. Mason, J. Hovsepian, J.L. Holtzman, J. Biol. Chem. 254 (1979) 4009-4014.
[2] C. Bryant, M. DeLuca, J. Biol. Chem. 266 (1991) 4119-4125.

[3] S. Zenno, H. Koike, A.N. Kumar, R. Jayaraman, M. Tanokura, K. Saigo, J. Bacteriol. 178 (1996) 4508-4514

[4] S. Zenno, K. Saigo, H. Kanoh, S. Inoue, J. Bacteriol. 176 (1994) 3536-3543.

[5] Y. Yanto, M. Hall, A.S. Bommarius, Org. Biomol. Chem. 8 (2010) 1826-1832.

[6] S. Zenno, H. Koike, M. Tanokura, K. Saigo, J. Biochem. 120 (1996) 736-744.

[7] H. Nivinskas, R.L. Koder, Ž. Anusevičius, J. Šarlauskas, A.-F. Miller, N. Čènas, Arch. Biochem. Biophys. 385 (2001) 170-178

[8] R.L. Koder, C.A. Haynes, M.E. Rodgers, D.W. Rodgers, A.-F. Miller, Biochemistry 41 (2002) 14197-14205.

[9] C.A. Haynes, R.L. Koder, A.-F. Miller, D.W. Rodgers, J. Biol. Chem. 277 (2002) 11513-11520.

[10] H. Koike, H. Sasaki, T. Kobori, S. Zenno, K. Saigo, M.E.P. Murphy, E.T. Adman, M. Tanokura, J. Mol. Biol. 280 (1998) 259-273.

[11] H.J. Hecht, H. Erdmann, H.J. Park, M. Sprinzl, R.D. Schmid, Nat. Struct. Biol. 2 (1995) 1109-1114.

[12] M.D. Roldan, E. Perez-Reinaldo, F. Castillo, C. Moreno-Vivian, FEMS Microbiol. Rev. 32 (2008) 474-500.

[13] J.C. Spain, Annu. Rev. Microbiol. 49 (1995) 523-555.

[14] R.J. Knox, P.J. Burke, S. Chen, D.J. Kerr, Curr. Pharm. Des. 9 (2003) 2091-2104.

[15] M. Jaberipour, S.O. Vass, C.P. Guise, J.I. Grove, R.J. Knox, L. Hu, E.I. Hyde, P.F. Searle, Biochem. Pharmacol. 79 (2010) 102-111.

[16] H. Nivinskas, S. Staškevičienė, J. Šarlauskas, R.L. Koder, A.-F. Miller, N. Čènas, Arch. Biochem. Biophys. 403 (2002) 249-258.

[17] D. Jarrom, M. Jaberipour, C.P. Guise, S. Daff, S.A. White, P.F. Searle, E.I. Hyde, Biochemistry 48 (2009) 7665-7672.

[18] G.N. Parkinson, J.V. Skelly, S. Neidle, J. Med. Chem. 43 (2000) 3624-3631.

[19] E. Johansson, G.N. Parkinson, W.A. Denny, S. Neidle, J. Med. Chem. 46 (2003) 4009-4020.

[20] P.R. Race, A.L. Lovering, R.M. Green, A. Ossor, S.A. White, P.F. Serale, C.J. Wrighton, E.I. Hyde, J. Biol. Chem. 280 (2005) 13256-13264.

[21] C. Barbey, N. Rouhier, A. Haouz, A. Navazza, J.-P. Jacquot, Acta Crystallogr., Sect. F 64 (2008) 29-31.

[22] J. Couturier, P. Prosper, A. Winger, A. Hecker, M. Hirasawa, D.Knaff, P. Gans, J.-P. Jacquot, A. Navazza, A. Haouz, N. Rouhier, Antiox. Redox Signal., 2012, (Epub ahead of print, PMID 22866991).

[23] A. Nemeikaitė-Čènienè, J. Šarlauskas, Ž. Anusevičius, H. Nivinskas, N. Čènas, Arch. Biochem. Biophys. 416 (2003) 110-118.

[24] V. Miškinienè, E. Sergedienè, A. Nemeikaitè, J. Segura-Aguilar, N. Čènas, Cancer Lett. 149 (1999) 217-222.

[25] T. Iyanagi, Free Radical Res. Commun. 8 (1990) 259-268.

[26] G.D. Buffinton, K. Öllinger, A. Brunmark, E. Cadenas, Biochem. J. 257 (1989) 561-571.

[27] N. Čènas, S. Prast, H. Nivinskas, J. Šarlauskas, E.S.J. Arner, J. Biol. Chem. 281 (2006) 5593-5603.

[28] J. Šarlauskas, A. Nemeikaitè-Čènienè, Ž. Anusevičius, L. Misevičienè, M. Martinez-Julvez, M. Medina, C. Gomez-Moreno, N. Čènas, Arch. Biochem. Biophys. 425 (2004) 184-192.

[29] P.D. Fiorella, J.C. Spain, Appl. Environ. Microbiol. 63 (1997) 2007-2015.

[30] J. Hawari, A. Halasz, S. Beaudet, L. Paquet, G. Ampleman, S. Thiboutot, Appl. Environ. Microbiol. 65 (1999) 2977-2986.

[31] N. Čènas, Ž. Anusevičius, H. Nivinskas, L. Misevičienė, J. Šarlauskas, Methods Enzymol. 382B (2004) 258-277.

[32] P. Wardman, J. Phys. Chem. Ref. Data 18 (1989) 1637-1755.

[33] P.G. Riefler, B.F. Smets, Appl. Environ. Microbiol. 68 (2002) 1690-1696.

[34] J. Šarlauskas, H. Nivinskas, Ž. Anusevičius, L. Misevičienė, A. Marozienė, Chemija 17 (2006) 31-37.

[35] A. Darchen, C. Moinet, J. Electroanal. Chem. 78 (1977) 81-88.

[36] C. Klomsiri, P.A. Karplus, L.B. Poole, Antioxid. Redox Signal. 14 (2011) 10651077.

[37] S. Viamajala, B.M. Peyton, L.A. Richards, J.N. Petersen, Chemosphere 66 (2007) 1094-1106.

[38] D.D. Emery, P.C. Faessler, Ann. N.Y. Acad. Sci. 829 (1997) 326-340.

[39] T. Kobori, H. Sasaki, W.C. Lee, S. Zenno, K. Saigo, M.E.P. Murphy, M. Tanokura, J. Biol. Chem. 276 (2001) 2816-2823.

[40] Ž. Anusevičius, J. Šarlauskas, N. Čènas, Arch. Biochem. Biophys. 404 (2002) 254-262.

[41] N. Čènas, Ž. Anusevičius, D. Bironaitė, G.I. Bachmatova, A.I. Archakov, K. Ollinger, Arch. Biochim. Biophys. 315 (1994) 400-406.

[42] Ž. Anusevičius, M. Martinez-Julvez, C.G. Genzor, H. Nivinskas, C. GomezMoreno, N. Čènas, Biochim. Biophys. Acta 1320 (1997) 247-255.

[43] G. Grampp, W. Jaenicke, J. Electroanal. Chem. 229 (1987) 297-303.

[44] M. Moetner, P. Neta, J. Phys. Chem. 90 (1986) 4648-4650.

[45] Ž. Anusevičius, L. Misevičienè, M. Medina, M. Martinez-Julvez, C. GomezMoreno, N. Čènas, Arch. Biochem. Biophys. 437 (2005) 144-150. 